\title{
PAŠTROVSKI PUKOVNIK NIKOLA MEDIN - ZAPOVJEDNIK MLETAČKIH PREKOMORSKIH PJEŠAČKIH SNAGA KONCEM 18. STOLJEĆA*
}

Lovorka ČORALIĆ

Hrvatski institut za povijest

Zagreb, Hrvatska
UDK: 355.1(450 Venezia): 929 Medin, N.

DOI: $10.21857 / \mathrm{y} 7 \mathrm{v} 64 \mathrm{t} 08 \mathrm{qy}$

Izvorni znanstveni rad

Prihvaćeno: 2. ožujka 2020.

Središnje istraživačko zanimanje u radu upravljeno je na vojnu karijeru Nikole Medina, podrijetlom iz Paštrovića (Conte di Castel Lastva), pukovnika mletačkih prekomorskih pješaka koncem 18. stoljeća. Rad je zasnovan na analizi izvornog gradiva iz Državnog arhiva u Zadru (fond: Generalni providuri za Dalmaciju i Albaniju) te - u većoj mjeri - dokumenata iz Archivio di Stato di Venezia (fond državne magistrature za vojna novačenja: Inquisitori sopra l'amministrazione dei pubblici ruoli). U uvodnom dijelu rada sažeto se donose opći podatci iz prošlosti Paštrovića u doba mletačkog vrhovništva s posebnim osvrtom na uključenost tamošnjeg stanovništva u mletačke prekojadranske kopnene postrojbe (Fanti oltramarini i Cavalleria Croati, odnosno Croati a cavallo). Iz analize je razvidno da su Paštrovići tijekom ranog novog vijeka izrazito aktivno participirali u rečenim mletačkim prekomorskim vojnim snagama, a među njima su se osobito isticali odvjetci obitelji Bečić i Medin. Tragom izvornog gradiva iz zadarskog arhiva utvrđuje se tijek napredovanja središnjeg protagonista rada - Nikole Medina - od dokapetana do pukovnika. Temeljem mletačkog gradiva prati se Medinovo djelovanje u činu pukovnika, pri čemu se posebice raščlanjuju popisi njegovih osobnih satnija od 1788. do 1796. godine s naglaskom na zavičajnom podrijetlu vojnika. Utvrđuje se kako se dio vojnika može ubrojiti u profesionalno pješaštvo, dočim je dio njih pripadao postrojbama teritorijalne milicije (cernidama). U prilogu na kraju rada donose se popisi vojnog ljudstva u ovdje analiziranim osobnim satnijama pukovnika Medina.

Ključne riječi: Nikola Medin, Fanti oltramarini, Paštrovići, Mletačka Republika, cernide, vojna povijest, 18. stoljeće.

\section{UVOD: OPĆI PODACI O PAŠTROVIĆIMA I CILJ RADA}

Paštrovići su područje u današnjem Crnogorskom primorju, smješteno između mora i područja Maina, Braića, Crmnice i Spiča, a najpoznatija tamošnja naselja su Bečići, Buljarica, Petrovac (nekadašnji Kaštel Lastva), Pržno i Sveti Stefan. Godine 1424. Paštrovići su priznali mletačku vlast te je ta činjenica u velikoj mjeri utjecala na gospodarsku usmjerenost tamošnjeg žiteljstva koje se - koristeći povoljan zemljopisni položaj, blizinu agrarno-stočarskog susjedstva

* Ovaj rad sufinancirala je Hrvatska zaklada za znanost projektom pod brojem 3675. 
te mogućnost pomorske plovidbe - već od 15. stoljeća sve više usmjerava na pomorsku trgovinu diljem Jadrana. Paštrovići su poglavito izvozili proizvode iz poljoprivrednog zaleđa (kožu, ulje, vunu, meso), a za potrebe Republike na svojim su brodovima prevozili albansko žito u sjevernodalmatinske luke, Istru i Mletke. Značajnu povlasticu paštrovski su trgovci stekli 1611. godine, kada im je mletački ured Magistrato delle Aque odredio pristanište na Riva degli Schiavoni te ondje potvrdio pravo na određen broj stolova za prodaju izvezenih proizvoda. Tada se u Paštrovićima izdvaja niz imućnih i poduzetnih obitelji (Davidović, Dobronić, Glavina, Gregorić, Junković, Kaštelan, Kažanegra, Markičević, Medin, Nikolić, Perazić, Stanišić, Šoljaga i druge) i pojedinaca, vlasnika i (ili) kapetana brodova koji trguju sa svim značajnijim lukama Sredozemlja. Međutim, teškoća u razvojnim sastavnicama Paštrovića u ranom novom vijeku zbila se započinjanjem osmanskih upada i osvajanjem neposrednog zaleđa toga kraja. Paštrovići su se već od druge polovice 15. stoljeća, a posebice od 16. stoljeća, izravno uključili u vojne snage koje su djelovale kako na očuvanju zavičaja tako i na obrani mletačkih stečevina od Dalmacije i Boke do grčkog arhipelaga. Sva izvješća mletačkom Senatu naglašavaju vjernost paštrovske općine Republici, odlike paštrovskih vojnika, ali istodobno bilježe i njihove stalne sukobe $s$ crnogorskim plemenima koja su nerijetko ratovala na strani Osmanlija. Teška stradanja paštrovski je kraj pretrpio tijekom Kandijskog rata (1645. - 1669.). Godine 1646. skadarski je paša s oko 1000 vojnika pokušao prodrijeti u samu dubinu paštrovske općine. Četiri godine kasnije isti je paša sa znatno više ljudstva (oko 6000 vojnika) istodobno napao Paštroviće, Maine i Grbalj te tom prilikom odveo velik broj ljudi u zatočeništvo. Osmanski napadi postigli su vrhunac od 1654. do 1656. godine, kada je dio stanovništva bio prisiljen izbjeći u sigurniju Boku. Najjači prodor Osmanlija zabilježen je u posljednjim godinama opstojanja Republike Svetog Marka, točnije 1785. godine. Tada je u pohodu skadarskog paše Mahmuda Bušatlije paštrovski kraj teško opustošen, a brojni civili pobijeni su ili su dopali u osmansko sužanjstvo. Te su okolnosti uzrokovale migracijske procese iz Paštrovića (izrazito učestalo u Mletke), ali su i dodatno utjecale na njihovo brojčano snažno pristupanje u mletačke postrojbe. ${ }^{1}$ Posebno se to odnosi

1 Podrobnije o prošlosti Paštrovića u kasnom srednjem i ranom novom vijeku vidi u radu Lovorke Čoralić, Iz prošlosti Paštrovića, Historijski zbornik, sv. 49, Zagreb, 1996., 137 - 159. Ondje su navedene i brojne bibliografske jedinice koje se odnose na svekolike razvojne sastavnice paštrovske povijesti toga vremena. Usporedi i kasnije nastale radove L. ČorALIĆ, Tragom oporuka bokeljskih i paštrovskih trgovaca u Mlecima (od kraja XV. do kraja XVI. stoljeća), Istorijski zapisi, god. 80, br. 1 - 4, Podgorica, 2007., 97 - 118; L. ČorALIĆ, Bokeljski, paštrovski i budvanski iseljenici i mletački arsenal (XV-XVIII stoljeće), Godišnjak Pomorskog muzeja u Kotoru, sv. 57 - 58, Kotor, 2010., 17 27; L. Čoralić, Iseljenici iz Paštrovića u Zadru (XVI.-XIX. st.), Historijski zbornik, god. 64, br. 1, 
na profesionalne kopnene snage u kojima su bili zastupljeni brojni Paštrovići, a mnogi su od njih tijekom karijere postigli časničke i dočasničke činove.

Središnja tema ovoga rada, koji je rezultat višegodišnjeg istraživanja mletačkog i zadarskog arhivskog gradiva koje se odnosi na udio Hrvata u mletačkim prekomorskim kopnenim snagama (Fanti oltramarini - pješaštvo i Cavalleria Croati ili Croati a cavallo - konjaništvo), ${ }^{2}$ usmjerena je na istraživanje vojne karijere članova paštrovsko-budvanske obitelji Medin, posebice pješačkog pukovnika Nikole Medina koncem 18. stoljeća. Rad se zasniva na obradi postojećih saznanja iz literature, kao i na uvidu izvornog arhivskog gradiva iz Archivio di Stato di Venezia (fond: Inquisitori sopra l'amministrazione dei pubblici ruoli, dalje: RI-ASVe-0715-Inquisitori ... pubblici ruoli) i Državnog arhiva u Zadru (fond: Generalni providuri za Dalmaciju i Albaniju, dalje: HRDAZD-1-GPDA). U radu ćemo ukratko opisati udio Paštrovića u mletačkim prekomorskim kopnenim snagama s posebnim osvrtom na obitelj Medin i njihove časnike. Drugi dio rada fokusiran je na samog pukovnika Nikolu Medina, sastav njegove pukovnije, kao i na raščlambu neke od satnija kojima je osobno zapovijedao.

\section{PAŠTROVIĆI U MLETAČKIM PREKOMORSKIM KOPNENIM SNAGAMA S POSEBNIM OSVRTOM NA OBITELJ MEDIN}

Uvidom u dokumente mletačke magistrature za novačenje kopnenih postrojbi Inquisitori sopra l'amministrazione dei pubblici ruoli saznajemo za brojne podatke o Paštrovićima - profesionalnim časnicima i vojnicima

Zagreb, 2011., 1 - 27; L. Čoralı́́, Iseljenici iz Paštrovića u Mlecima (15. - 18. stoljeće), Paštrovski almanah, sv. 2, Petrovac - Sveti Stefan, 2017., 525 - 546; L. Čoralić, Pukovnik mletačkih prekomorskih pješaka Juraj Medin (kraj 17. i početak 18. stoljeća), Historijski zbornik, god. LXXII, br. 1, Zagreb, 2019., $47-62$.

2 Podrobnije o vojnoj povijesti istočnog Jadrana u ranom novom vijeku vidi literaturu u radu Lovorke Čoralić i Maje KaTUŠić, Šibenčani u mletačkim prekojadranskim kopnenim postrojbama (18. stoljeće), Radovi Zavoda za povijesne znanosti HAZU u Zadru, sv. 58, Zagreb - Zadar, 2016., 148 (bilješka 1). Ovome valja pridodati i vrsne radove Nikole MARKulina, Vojno poduzetništvo u Mletačkoj Dalmaciji i Boki za vrijeme Morejskog rata (1684. - 1699.), Radovi Zavoda za povijesne znanosti HAZU u Zadru, sv. 56, Zagreb - Zadar, 2014., 91 - 142; Mletačka vojna organizacija u Dalmaciji i Boki od Morejskog rata (1684. - 1699.) do Požarevačkog mira 1718., doktorski rad, Zadar, 2015.; Nikola MarkuLin, Vojno poduzetništvo u Mletačkoj Dalmaciji i Boki od 1700. do 1718. godine, Povijesni prilozi, god. 35, sv. 51, Zagreb, 2016., 159 - 196. Kada je riječ o udjelu Hrvata, kao i pripadnika drugih naroda s istočnojadranske obale u mletačkim prekomorskim kopnenim snagama, usporedi bibliografske jedinice u radu L. Čoralıć, Albanski vojnici u mletačkim prekojadranskim kopnenim postrojbama (18. stoljeće), Povijesni prilozi, god. 37, br. 54, Zagreb, 2018., 185 - 186 (bilješka 4). 
u pješačkim i konjaničkim jedinicama u 18. stoljeću. Prema dosadašnjim istraživanjima, tijekom 18. stoljeća zabilježeno je nešto više od šezdeset paštrovskih vojnika u postrojbama Fanti oltramarini i Cavalleria Croati. $\mathrm{Na}$ pješačke postrojbe otpadalo je 87,30 \% Paštrovića, dočim su u konjaništvu bili zastupljeni s 12,70 \%. Takav omjer ne začuđuje. Naime, istovremeno je djelovalo oko deset prekomorskih pješačkih pukovnija, a unutar njih sedam do deset satnija s oko pedeset do šezdeset vojnika. Konjaničke su pukovnije bile manje brojne, najčešće ih je bilo pet do šest, od kojih su dvije do tri bile Cavalleria Croati, a ostale draguni. Unutar konjaničkih pukovnija djelovalo je obično šest do sedam satnija. Razlog ovakvim omjerima između pješaka i konjanika jest činjenica da su konjaničke postrojbe iziskivale veća financijska sredstva za opremu i oružje, ali i za plaće njima pripadajućeg vojnog ljudstva. Nadalje, djelovanje Paštrovića unutar raznih pukovnija odnosilo se na mletačke stečevine duž Terraferme (Veneta), istarskih, dalmatinskih i bokeljskih vojnih uporišta, kao i na posjede Serenissime na području Grčke. Iako su, poput većine pješaka i konjanika zavičajem s istočnog Jadrana, najčešće zabilježeni kao obični vojnici ili obnašatelji nižih činova, Paštrovići se često spominju i kao visoki vojni časnici. Pri tome je najčešće riječ o odvjetcima uglednih vojničkih obitelji Bečić i Medin te je upravo potonja obitelj, točnije pukovnik Nikola Medin, u središnjem zanimanju nastavka rada.

Obitelj Medin potječe iz Paštrovića, najvjerojatnije iz Kaštel Lastve (današnji Petrovac). U izvorima se učestalije spominje od 16. stoljeća, kada je (1576.) car i kralj Maksimilijan II. braći Mihovilu i Gašparu Medinu (1576.) podijelio ugarsko-hrvatsko plemstvo. Godine 1747. neki su odvjetci obitelji (kapetan Stjepan i njegov sin Jeronim, zatim kapetan Andrija i braća Ivan Krstitelj i Jacint) upisani u mletački Libro aureo. U istu su knjigu upisani 1791. godine, s naslovima conti di Lastva, e nobili del Regno d'Ungaria, Jeronim, Petar Ivan, Ivan Krstitelj i Albert Ivan, sinovi Stjepana Medina, a gotovo pred sam kraj Republike i Nikola (u središnjem istraživačkom zanimanju ovoga rada) te Ivan Alvize i Antun Frano, sinovi Andrije Medina. ${ }^{3} \mathrm{Na}$ ovome je mjestu nužno spomenuti da su paštrovski Medini u 18. stoljeću uglavnom bili pravoslavne vjere. Neki su ogranci te obitelji katoličke vjeroispovijesti radi progona tamošnjeg, većinski pravoslavnog žiteljstva, $s$ vremenom napustili zavičaj - isprva u Budvu, a potom i

3 Carl Georg Friedrich Heyer von Rosenfeld, Der Adel des Königreichs Dalmatien, Nürnberg, 1873. (pretisak: Zagreb, 1995.), 120 - 121; Miroslav Granić, Denis Martinović, Plemstvo Kraljevine Dalmacije 1814. - 1918., Zadar, 2018., 353. 
u druge gradove duž istočnog Jadrana. ${ }^{4}$ Takav su slučaj i časnici i vojnici iz obitelji Medin koje ćemo ukratko spomenuti u ovom radu, a to se zasigurno odnosi i na pukovnika Nikolu Medina.

Raščlambom spisa magistrature Inquisitori sopra l'amministrazione dei pubblici ruoli doznajemo za niz članova obitelji Medin koji su obnašali časničke činove. Kada je riječ o konjaništvu, to su primjerice pukovnik Antun, dopukovnik (Colonnello in secondo) Marko te kapetan Toma, zabilježeni kao zapovjednici postrojbi koje su u 18. stoljeću bile stacionirane na mletačkim stečevinama u Grčkoj. ${ }^{5}$ Kako je prethodno objašnjeno, Paštrovići su, te tako i članovi obitelji Medin, ponajprije bili prisutni u pješačkim postrojbama. Najviše su činove postigli pukovnici Juraj (od oko 1694. do kraja dvadesetih godina 18. stoljeća) i Nikola (o kome će nešto kasnije biti više riječi), kao i bojnik Stjepan (1758. - 1764.), ${ }^{6}$ a niz je odvjetaka obitelji Medin obnašao dužnost kapetana. To su, navedimo samo neke, Andrija (1750. - 1764.), Franjo (1714.), Franjo (1796.), Gabrijel (1789. - 1796.), Ivan Alvise (1788. - 1797.), Marko (1767.), Petar (1792. - 1796.) i drugi. ${ }^{7}$ Iz prethodno navedenog razvidna je vrlo aktivna uključenost Medina u mletačke prekomorske, ponajprije pješačke postrojbe, što je najbolje dokumentirano za 18. stoljeće. Mjesta djelovanja odnosno prisustva njihovih pukovnija i satnija zahvaćala su cjelokupan mletački državni teritorij, a izrazita međusobna obiteljska umreženost (prisutnost više članova obitelji unutar iste pukovnije ili satnije) svjedoči kako je riječ o tipičnom primjeru vojnog poduzetništva u koji su bile uključene brojne, ponajprije plemićke obitelji $s$ istočnog Jadrana.

\section{PUKOVNIK NIKOLA MEDIN I NJEGOVA PJEŠAČKA PUKOVNIJA}

Prvi podatci koje, prema dosadašnjim saznanjima, posjedujemo o Nikoli Medinu potječu iz šezdesetih godina 18. stoljeća. Tada je (31. kolovoza 1768.), $\mathrm{u}$ vrijeme generalnog providura Dalmacije i Albanije Antonija Reniera (1765. - 1768.), Nikola Medin imenovan dokapetanom (Capitan tenente) u pješačkoj (oltramarinskoj) postrojbi tada već pokojnog pukovnika Macedonia. U spisu

4 Prema pisanju Jovana Vukmanovića (Paštrovići: Antropogeografsko-etnološka studija, Podgorica, 2002., 42), progoni katolika, ponajprije članova ugledne obitelji Medin, dosezali su toliko daleko da je sklapanje braka s pravoslavcima podlijegalo strogoj plemenskoj kazni.

RI-ASVe-0715-Inquisitori ... pubblici ruoli, b. 821 - 823.

RI-ASVe-0715-Inquisitori ... pubblici ruoli, b. 648 - 649, 517 - 523.

7 RI-ASVe-0715-Inquisitori ... pubblici ruoli, b. 550, 703, 648, 633, 454, 651 - 653, 492B, 639. Brojevi busta odgovaraju slijedu nabrajanja kapetana iz obitelji Medin. 
se još navodi kako je 1744. godine unovačena, između ostalih, jedna pješačka satnija (compagnia) kojom je zapovijedao Andrija Medin. Potonji je za zastavnika (Alfier) postavio svoga sina Nikolu, ali je satnija (moguće radi nedovoljnog broja vojnika) ubrzo raspuštena. Nikola Andrijin nastavio je službu kao pričuvni zastavnik u pukovniji Macedonia te se istaknuo služeći u Dalmaciji, Boki kotorskoj (odnosno Mletačkoj Albaniji), na Levantu te u okršajima s gusarima. ${ }^{8}$ Čini se da je napredovanje Nikole Medina bilo ubrzano jer je već 4. veljače 1769. (vrijeme djelovanja generalnog providura Domenica Condulmera) promaknut $\mathrm{u}$ čin kapetana prekomorskih pješaka u pukovniji Petra Rada. Naime, tada je u istoj pukovniji preminuo jedan od kapetana satnije (Bortolo Zulatti), a Nikola je kao najstariji po činu postavljen na njegovo mjesto. ${ }^{9}$

Podatci o djelovanju Nikole Medina koje saznajemo na osnovi spisa generalnih providura za Dalmaciju i Albaniju tek nam djelomično govore o njegovoj vojnoj karijeri. Potpuniji podatci o Nikoli Medinu sadržani su u popisima vojnika mletačke magistrature za novačenje. Tako iz 1769. godine (31. listopada), kada je i imenovan kapetanom u pukovniji Petra Rada, potječe podatak kako je Nikolina satnija, zajedno sa satnijama kapetana Antuna Buće, Antuna Mihovilovića i Antuna Mirdite, bila stacionirana i popisana u Kotoru. ${ }^{10}$

Najpotpuniji podatci o djelovanju Nikole Medina u činu pukovnika pohranjeni su u istom arhivskom fondu (b. 650 - 655) i datiraju od 1785. do 1797. godine. ${ }^{11}$ Tada su se, promatrano kroz cijelo razdoblje, u sastavu pukovnije Medina nalazile satnije kojima su zapovijedali sljedeći časnici koje navodimo abecednim redom uz podatke o godini i mjestu popisivanja vojnog ljudstva: ${ }^{12}$ kapetan Antun Alačević (Mletci, 1793. i 1795.), kapetan Franjo Antoniolli (bez mjesta, 1788.), kapetan Nikola Barbarić (Mletci, 1789.), dopukovnik Donà Cleva (Kotor, 1788.), dopukovnik Giovanni Battista Cristofoli (Zadar, 1792.; Verona, 1794. i 1795.), kapetan Marco Antonio Cristofoli (Kotor, 1791.; Zadar, 1792. i 1793.; Mletci, 1793. i 1794.), kapetan Donà Dobrilević (Zadar, 1785.), kapetan

8 HR-DAZD-1-GPDA, kut. 165, fol. 164v - 165.

9 HR-DAZD-1-GPDA, kut. 170, fol. 28v - 29. Podatke za ovu i prethodnu bilješku ljubazno mi je pribavio dr. sc. Nikola Markulin te mu na tome iskreno zahvaljujem.

10 RI-ASVe-0715-Inquisitori ... pubblici ruoli, Fanti oltramarini, b. 686, Reggimento Pietro Rado (1768. - 1778.), Compagnia Nicolò Medin, Cattaro, 31. Ottobre 1769.

11 Ovdje treba napomenuti da se na ovitku svežnjeva navodi kako je riječ o pukovniji Nikole i Jurja Medina. Međutim, ovdje su gotovo isključivo sadržane satnije Nikole Medina, dočim su one vezane za pukovnika Jurja u svežnjevima $648-649$.

12 Ovih je popisa zasigurno bilo i više od ovdje navedenih. Međutim, ovdje iznosimo podatke prema stanju sačuvanosti gradiva. 
Juraj Jeronim Felicinović (Verona, 1796.), ${ }^{13}$ dopukovnik Mattio Filaretto (Zadar, 1792. i 1794.; Mletci, 1794., 1796.; ${ }^{14}$ Verona, 1796.), kapetan Ivan Almaro Galović (Kotor, 1786.; Mletci, 1788. i 1789.), kapetan Zuanne Isii (Mletci, 1786.),, bojnik Ivan Dražoje Jelić (Mletci, 1785., $1786 .{ }^{16}$ i 1788.), kapetan Alvise Kumbat (Krf, 1790.), ${ }^{17}$ kapetan Giacinto Matiazzi (Kotor, $1790 .{ }^{18}$ i 1791.; Zadar, 1792. i 1793.; Mletci, 1793. i 1797.; Brescia 1792., 1793. i 1794.; ${ }^{19}$ Verona, 1796.; Porto Santa Croce in Ragusi, ${ }^{20}$ 1790.), kapetan conte Gabrijel Medin (Mletci, 1790. 1791., 1793. i 1796.; Krf, 1794.; Verona, 1796. $\left.{ }^{21}\right)$, kapetan conte Petar Medin (Zadar, 1792.; Mletci, 1793.;22 Bergamo, 1794.), kapetan Matija Meštrović (Mletci, 1796. ${ }^{23}$ ); kapetan Jeronim Franjo Michieli Vitturi (Mletci, 1796.), ${ }^{24}$ bojnik Nikola Michieli Vitturi (Hvar, 1791.; Zadar, 1792. i 1793.), kapetan Lovro Milanović (Mletci, 1794. i 1796.; Udine, 1794. ${ }^{25}$; Verona, 1796.), kapetan Danijel Petrović (Kotor, 1788.; Zadar, 1789.), kapetan Josip Petrović (Verona, 1796.; Mletci, 1796.), kapetan Damjan Miko Sudarević (Mletci, 1788.), kapetan Matija Sudarević (Mletci, 1788.), ${ }^{26}$ kapetan Pietro Vechietti (Mletci, 1796. ${ }^{27}$ i kapetan Zorzi Vlasto (Mletci, 1796.; Verona, 1796.). Navedeni popisi pokazuju nam kako su u pukovniju Nikole Medina bili uključeni i drugi članovi obitelji Medin (kapetani Petar i Gabrijel) te je taj podatak važan jer nam posvjedočuje o činjenici da je vojno poduzetništvo u nemaloj mjeri temeljeno na obiteljskim vezama, odnosno uključivanju članova obitelji u postrojbe koje je novačio jedan od (starijih) odvjetaka. Jednako tako, pukovnija Nikole Medina s pripadajućim satnijama djelovala je u posljednjim desetljećima opstojanja Mletačke Republike kada su, po posljednji puta, novačene brojčano snažnije vojne postrojbe. Otuda i činjenica da su bile popunjavane, uz profesionalne pješake, postrojbama teritorijalne milicije (cernide, krajine) te u nemalom broju primjera bilježimo $u$

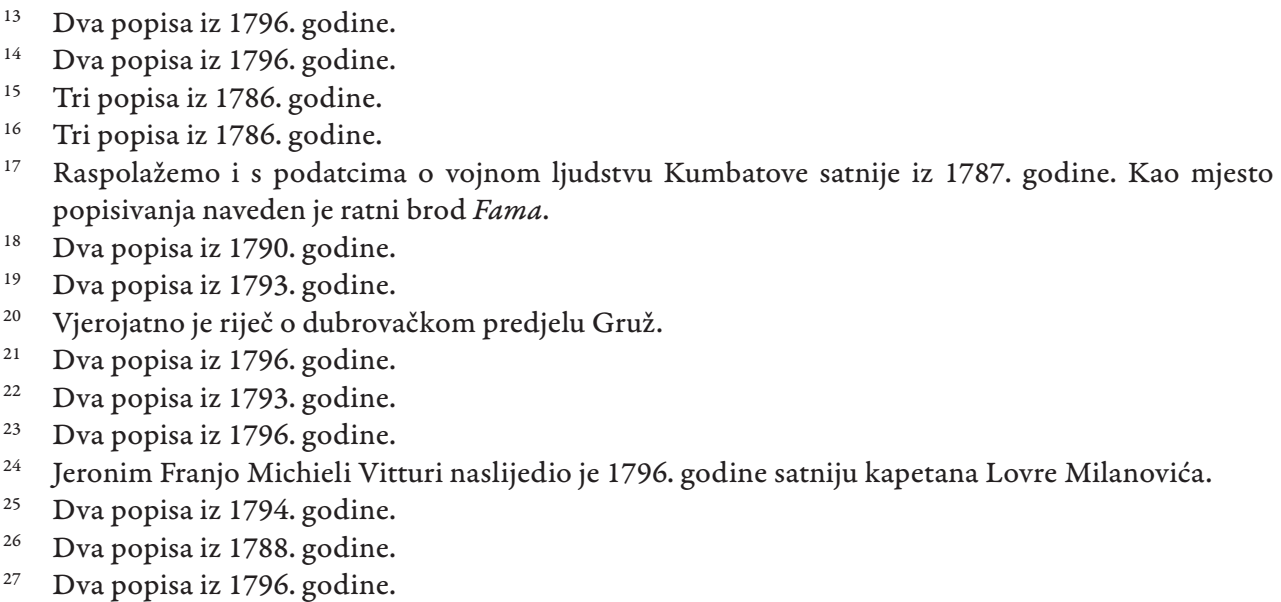


većini satnija iz devedesetih godina 18. stoljeća mnogo veći broj vojnika nego što je to bilo uobičajeno. Na primjeru osobnih satnija Nikole Medina ta se činjenica može izravno potkrijepiti.

U nastavku rada fokusirat ćemo se na osobne satnije (compagnia propria) pukovnika Nikole Medina. Najprije ćemo ih sve nabrojiti uz osnovne podatke o mjestu i vremenu popisivanja, a potom ćemo izdvojiti neke od satnija i statistički ih podrobnije obraditi. U prilogu rada objavit ćemo popis vojnog ljudstva nekih od Medinovih pješačkih satnija toga vremena. Na osnovu uvida u svežnjeve 650 - 655 magistrature Inquisitori sopra l'amministrazione dei pubblici ruoli možemo utvrditi da su pukovnikove osobne satnije bile popisane i stacionirane u Mletcima (30. lipnja 1788., 30. lipnja 1789., 28. veljače 1790., 30. ožujka 1790., 31. rujna 1790., 27. rujna 1794., 31. prosinca 1796.), Zadru (25. ožujka 1792.), Vicenzi (24. lipnja 1794., 28. kolovoza 1794.) i Veroni (15. srpnja 1796.). Za ovu prigodu razmotrit ćemo neke od tih popisa te podrobno ukazati na sastav i značajke vojnog ljudstva kojime je osobno zapovijedao.

Prvi popis koji će biti predmet naše obrade načinjen je u Mletcima 30. lipnja 1788. godine. ${ }^{28} \mathrm{U}$ svom osnovnom sastavu postrojba je tada brojila 54 vojnika. Časnički i dočasnički kadar činili su, uz pukovnika Medina, još i dokapetan (Capitan tenente) Zuanne Rosani, zastavnik (Alfier) Zuanne Benedetti, narednik (Sargente) Josip Mialović te kaplari (Caporal) Marko Krapanić, Ivan Vrbanić i Mijat Lisac. Postrojbi su bili pridruženi i kadet (Cadetto) Teodoro Cortese, bubnjar ( Tamburo) Petar Cvitanović i pifarist (Piffaro) Mijo Radošević. Osnovnoj postrojbi naknadno su priključena još 44 vojnika, među kojima je naveden i kadet Petar Valeri. Nadalje, zasebnu stavku u popisu čine „prekobrojni vojnici“ (Sopranumerati) kojih je bilo 33, a među njima su viši kapetan (Capitano supremo) Nikola Barbarić, viši zastavnik (Alfier supremo) Marko Barbarić, zastavnici Nikolica Medin, Andrija Durante, Ivan Dima, Ivan Andrija Mihovilović i Juraj Kumbat, poručnik (Tenente) Agustin Kožul, narednici (Sargente) Petar Oršić i Juro Banovac, kaplari Antun Paramitiati, Ellia Stratti, Jure Petrović i Giulio Napoli te kapelani (Cappellano) o. Franjo Bašić i Ivan Ballarin. Uz navedene, prekobrojan dio jedinice činilo je još 17 mornara (Mariner).

Zanimljivo je raščlaniti zavičajnu strukturu vojnika iz osobne satnije pukovnika Medina (vidi: Grafikon 1). ${ }^{29}$ Prema raspoloživim podatcima,

28 RI-ASVe-0715-Inquisitori ... pubblici ruoli, Fanti oltramarini, b. 650, Reggimento Medin Nicolò, Compagnia propria (Mletci, 30. lipnja 1788.). Vidi prilog broj 1 na kraju rada.

29 Ovdje je potrebno napomenuti da su podatci o mjestu podrijetla najčešće vezani prije svega za profesionalni, odnosno osnovni dio satnije, kao i za dio naknadno dopisanih vojnika. U primjerima prekobrojnih članova postrojbe, zapisivači taj podatak nisu unosili. 


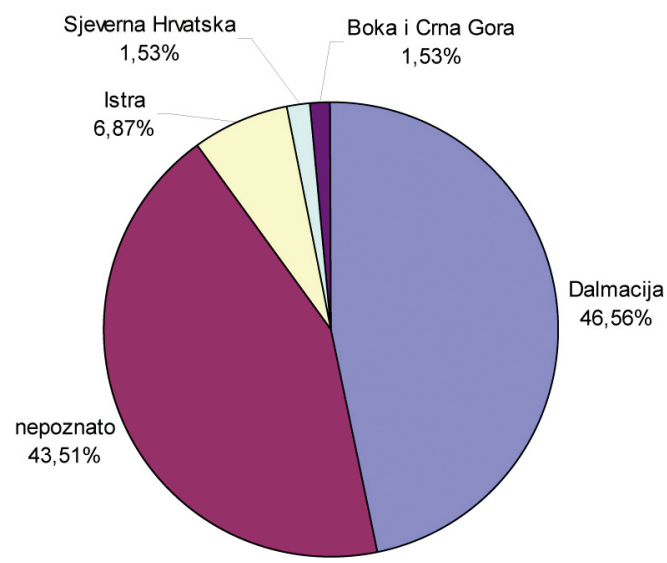

GrAfIKON 1. Zavičajno podrijetlo vojnika iz osobne satnije pukovnika Nikole Medina prema popisu načinjenom u Mletcima 30. lipnja 1788. godine

većina vojnika potjecala je s područja Dalmacije (46,56 \%), a uz veća gradska i komunalna središta (Zadar, Šibenik), kao i neka druga, ipak u osnovi urbana mjesta (Knin, Korčula, Krk, Makarska, Osor, Pag, Rab, Sinj, Skradin i druga) učestalo se bilježe i manja naselja na području od Zadra do Neretve (primjerice, Biljane, Biograd, Islam, Lišane Ostrovičke, Murter, Pađene, Pirovac, Primošten, Raštane, Rogoznica, Tisno, Tribanj, Vodice i druga). Za dio vojnika podrijetlo nije iskazano (43,51\%), ali možemo na osnovi njihovih prezimena s velikom vjerojatnošću pretpostaviti da su podrijetlom $s$ istočnojadranske obale, prije svega iz ruralnih krajeva. Nasuprot tomu, Sopranumerati (posebice mornari) vjerojatno su Talijani ili Grci. Istrani su u ukupnom omjeru zastupljeni sa 6,87 \% (Kopar, Motovun, Poreči Rovinj), dočim na vojnike iz sjeverne Hrvatske (Rijeka i vojnik označen kao Croato) otpada malenih 1,53\%. Naposljetku, jednak postotni omjer odnosi se na područje Paštrovića, a u oba je primjera riječ o članovima obitelji Medin (pukovnik Nikola i zastavnik Nikolica).

Popisivači su u nekim primjerima, iako neredovito, bilježili i fizičke značajke vojnog ljudstva. Tako saznajemo da su najmlađi vojnici imali 18 godina (primjerice, Luka Kazaro i Aleksa Vukobratović iz Pađena, Jakov Škrapić iz Murtera, Marko Dragić iz Tribanja, Grga Grapić iz Primoštena i drugi). Najstariji vojnik bio je star 30 godina, a riječ je o Frani Kokoliću iz Rovinja. Prosjek godina Medinovih vojnika iznosio je 22 godine, što je i očekivano kada je riječo pješačkim pukovnijama i njima pripadajućim satnijama. Drugačiju sliku dobili bismo usporedbom $s$ konjaničkim postrojbama kojih je u pravilu uvijek bilo manje, njihovo izdržavanje znatno skuplje, a vojnici koji su u njih bili novačeni u pravilu 
su bili već prokušani, vješti ratnim znanjima i stoga dobno stariji. Popisivači su za dio vojnika bilježili i staturu (visinu) i boju kose, a u svim primjerima riječ je o njihovu opažanju prema kojemu su Medinovi vojnici isključivo srednjeg rasta (ordinario) i smeđe boje kose (castagno). Takvi, ipak mislimo stereotipni prikazi sastava neke satnije nisu rijetkost te - na razini cjelovitijeg promatranja mletačkih prekomorskih pukovnija - tek manji broj popisivača neke vojnike opaža kao visoke (alto), niske (piccolo), crnokose (nero), plavokose (biondo), sjedokose (griso) i slično.

Sljedeći popis koji ćemo razmotriti načinjen je u Zadru 1792. godine (25. ožujka). ${ }^{30}$ Opažamo da je, u odnosu na prethodno raščlanjen popis, broj vojnika u osobnoj satniji pukovnika Medina znatno smanjen. U svom osnovnom sastavu satnija je brojila 38 časnika, dočasnika i običnih vojnika, a naknadno ih je dopisano još 19. U ovome primjeru kategoriju Sopranumerati više ne nalazimo. Primjećuje se, nadalje, da je - već i uslijed smanjenja ukupnog broja vojnog ljudstva sastav satnije znatno izmijenjen $u$ odnosu na prethodno analiziran popis. Kada je riječ o časničkom i dočasničkom kadru te o obnašateljima specijaliziranih službi, u osnovnom sastavu satnije bilježe se, uz pukovnika Medina, narednik Jure Bankovac, kaplar Ivan Jelinić te kadet Petar Ivan Andrija Burović iz Boke kotorske, bubnjar Ivan Sdubić iz Paga i pifarist Ilija Šarić iz Banjevaca. Među dočasničkim dijelom satnije koji je naknadno dopisan izrijekom su zabilježeni zastavnik Nikola Nakić i kaplar Krstitelj Roščević iz Istre.

Zavičajno podrijetlo pokazuje, doduše, da su najčešće spominjane regije, odnosno krajevi iz kojih dolaze vojnici i dalje vezani za Dalmaciju, ponajprije tamošnje ruralne sredine. Statistički promatrano (vidi: Grafikon 2) iz Dalmacije je potjecalo 61,40 \% vojnika. Uz veća gradska središta poput Zadra, Šibenika i Trogira, kao i također urbana mjesta poput Makarske, Paga, Raba i Visa, većina vojnika dolazila je iz malenih mjesta (Banjevci, Bilišane, Grab u Imotskoj krajini, Kaštela, Kruševo, Kukljica, Pirovac, Podgorje, Posedarje, Privlaka, Rogoznica, Vrsi, Zelengrad, Zemunik i druga). U skupini nepoznatog, odnosno neiskazanog podrijetla zabilježeno je 17,54 \% vojnika, dočim je s područja Boke kotorske i Crne Gore dolazilo njih 8,77 \% (Kotor, Paštrovići, Montenegro). Naposljetku, s malenim su postotnim udjelom zastupljeni vojnici iz Istre (označeni kao Istria - 5,26 \%), iz sjeverne Hrvatske (Gospić i Karlovac - 3,51 \%) te s područja Hercegovine (Trebinje - 1,75\%). 


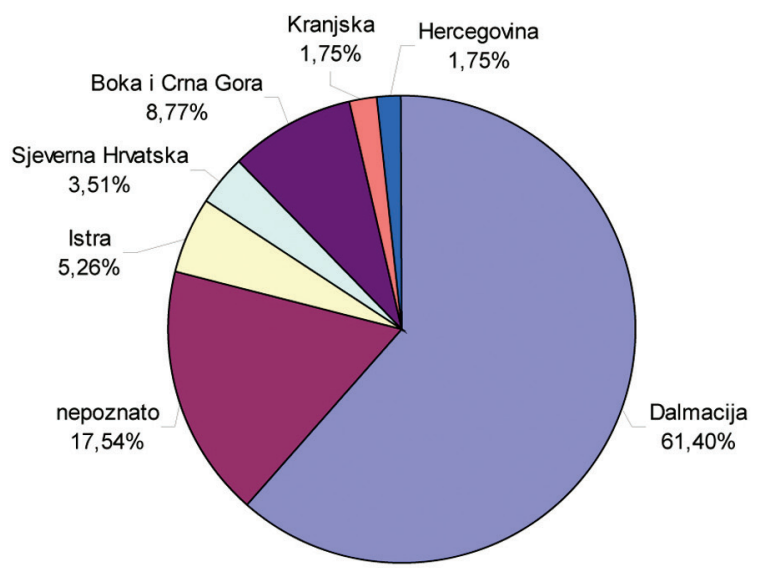

Grafikon 2. Zavičajno podrijetlo vojnika iz osobne satnije pukovnika Nikole Medina prema popisu načinjenom u Zadru 25. ožujka 1792. godine

Završavajući raščlambu ovoga dijela rada, potrebno je na kraju napomenuti da u ovom popisu nisu zabilježeni podatci o dobi i fizičkim karakteristikama vojnika.

Godine 1794. (24. lipnja) načinjen je u Vicenzi još jedan popis osobne satnije Nikole Medina. ${ }^{31}$ Satnija je u svom prvotnom sastavu brojila 42 profesionalna vojnika, ${ }^{32}$ a naknadno ih je dopisano još 37 . U odnosu na prethodni popis iz 1792. godine, velik broj profesionalnih vojnika ostao je isti, a shodno tomu i u ovom primjeru prevladavaju Dalmatinci zavičajem sa zadarskog, šibenskog i splitskog područja (iz gradova, kopnenog zaleđa i s otoka) te držimo da ovaj dio popisa nije potrebno izrijekom navoditi u prilogu rada. Mnogo je zanimljiviji uvid u cernide koji su naknadno dopisani i ukupno ih je 37. Naime, gotovo svi (osim jednog vojnika iz Klisa), potječu iz malenih mjesta u okolici Šestanovaca i iz Blata na Cetini (vidi: Grafikon 3). Postotnim omjerom, unutar cernida, prednjače vojnici iz Žeževice (32,43 \%) i Katuna (27,03 \%), a slijede ih vojnici (uključivo i kaplara Antuna Vuškovića) iz Blata na Cetini (21,62 \%) te iz Kreševa (16,22 \%). Ovaj podatak svjedoči nam kako su se, uslijed nedostatka profesionalnih vojnika u posljednjim godinama opstojanja Serenissime, novačenja vršila na mnogo široj

31 RI-ASVe-0715-Inquisitori ... pubblici ruoli, Fanti oltramarini, b. 652, Reggimento Medin Nicolò, Compagnia propria (Vicenza, 24. lipanj 1793.). Vidi prilog broj 3 na kraju rada.

32 Uz pukovnika Medina, kao časnici i dočasnici u ovom se popisu spominju zastavnici Nikola Mačić i Ivan Šubić, narednik Jure Banovac i kaplar Toma Lević. Kao bubnjar zabilježen je Antun Milošević iz Šibenika. 


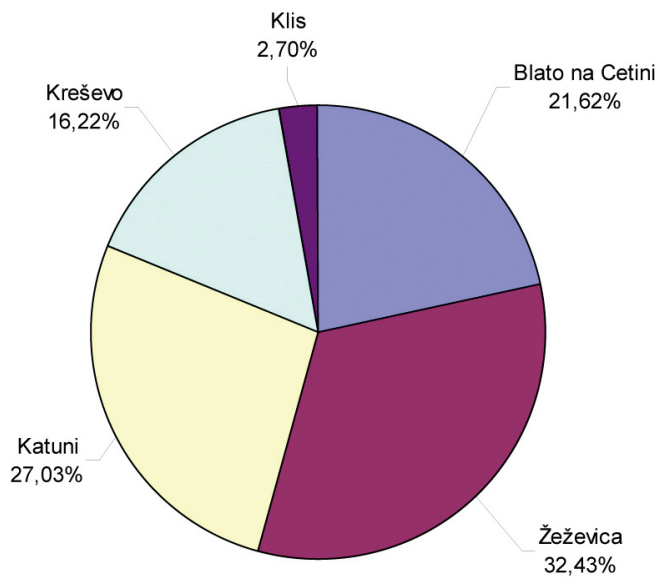

Grafikon 3. Zavičajno podrijetlo cernida iz osobne satnije pukovnika Nikole Medina prema popisu načinjenom u Vicenzi 24. lipnja 1794. godine

razini, ali su zahvaćala ciljane mikroregije. S obzirom na to da je riječ o naseljima s relativno malo stanovnika, ovaj broj vojnika, odnosno radno sposobnog muškog stanovništva, zasigurno je donosio nemale gospodarske gubitke za svako od ovdje navedenih mjesta. Također, kao i u prethodnom popisu, i ovdje nisu zabilježeni podatci o dobi i fizičkim značajkama kako profesionalnih vojnika tako i pripadnika cernida.

Sljedeći podatci koji se odnose na osobne satnije Nikole Medina nalik su, barem kada je riječ o profesionalnim vojnicima, prethodno raščlanjenim popisima. Stoga ćemo razmatranje osobnih satnija pukovnika Nikole Medina završiti osvrtom na završni popis, načinjen u Mletcima na Silvestrovo 1796. godine, svega godinu dana prije utrnuća Republike Svetog Marka. ${ }^{33}$ U svojemu je osnovnom sastavu satnija brojila 115 časnika, dočasnika i običnih vojnika. ${ }^{34}$ Od toga broja četrdeset je profesionalnih vojnika, dočim su ostali (iako dijelom

33 RI-ASVe-0715-Inquisitori ... pubblici ruoli, Fanti oltramarini, b. 654, Reggimento Medin Nicolò, Compagnia propria (Mletci, 31. prosinac 1796.). Vidi prilog broj 4 na kraju rada.

34 Kao časnici navode se, uz samoga pukovnika, zastavnik Angelo Paolo Bianchi, poručnik Ivan Vidrić, narednici Ivan Vuletić iz Kaštela i Aleksa Graovac, kaplari Antun Večaralo iz Zadra te Niko Milošina Filipov i Grgo Milošina Matin, kadeti Kamilo Milanović i Petar Maras (za kojega je dopisano da je nipote del Colonnello), a kao glazbena se pratnja bilježe Antun Milošević iz Šibenika i Juraj Majer iz Zadra. 
„pomiješani“ s potonjima, odnosno nisu navedeni kao naknadno dopisani) pripadnici cernida. ${ }^{35}$ Zavičajno podrijetlo profesionalnih vojnika nalik je prethodnim popisima te prevladavaju Dalmatinci iz prethodno navedenih gradova i manjih mjesta od Zadra do Splita. U ovome dijelu rada pozabavit ćemo se cernidama koje su, kako vidimo, činile pretežit dio ove brojčano velike satnije. Sobzirom na to da ni u ovom popisu nemamo podatke o dobi i fizičkim osobinama vojnika, usmjerit ćemo se isključivo na zavičajno podrijetlo pripadnika cernida (vidi: Grafikon 4). Prednjače, popisani doslovno jedan iza drugoga, cernide označene Narenta (22,67 \%), a slijede ih vojnici iz Makarske ili makarskog kraja $(18,67 \%)$ te $s$ istim postotkom oni iz Istre, unutar koje se kao mjesto podrijetla (uz opću oznaku Istria) bilježe malena naselja Vižinada i Kaštelir Labinci. Kada je riječ o cernidama s područja Šestanovaca i Cetinske krajine, ponovno se, ali u manjem broju bilježe cernide iz Kreševa (5,33 \%), Žeževice i Katuna (po 4,00 \%) te iz Blata na Cetini (1,33\%). Iako nismo sasvim sigurni je li riječ o cernidama ili profesionalnim vojnicima, u popisu koji se ponajviše odnosi na teritorijalnu miliciju spominju se i Sinjani (2,67 \%) te sa istim postotkom vojnici iz Krajine (Craina). Dio vojnika, koji su bez sumnje pripadali cernidama, nije označen prema mjestu podrijetla, već po zapovjedniku (najvjerojatnije glavaru sela) koji im je bio svojevrstan zapovjednik i koji je posredovao u postupku njihova novačenja i uključivanja u postrojbu Fanti oltramarini. Ti se vojnici označavaju prema "zastavama“ (bandiera) te tako u ovom popisu nalazimo pripadnike pješačke jedinice u bandiera Sunara (2,67 \%), Medić, Maleš i Bužančić (svi po 4,00 \%), kao i u bandiera Despotović (5,33 \%). Iako je teško ustanoviti točno, odnosno uže zavičajno podrijetlo ovih vojnika, možemo - prema njihovim prezimenima - $s$ velikom vjerojatnošću smatrati da ga možemo smjestiti u dalmatinsko zaleđe (sinjski i drniški kraj, okolica Solina). Ovdje još jednom treba ponoviti da su cernide, nerijetko nazivane po glavaru takvih manjih skupina vojnika, pripajane profesionalnim pješačkim postrojbama u zadnjim godinama opstojanja Mletačke Republike. Najčešće su njihovo novačenje i dužina boravka izvan zavičaja trajali kratko, dijelom i iz razloga što nije bila riječ o profesionalnim snagama, već lokalnoj, teritorijalnoj miliciji, nenavikloj na ratne uvjete i ne baš dobro tretiranoj od stane njihovih sunarodnjaka koji su vojnu službu obnašali duže i raspolagali znatno većim vojnim vještinama.

35 Iako su svi vojnici navedeni u jedinstvenom popisu, možemo $s$ velikom vjerojatnošću izdvojiti (uz manje moguće pogreške) pripadnike cernida. Razlog je u tome što su grupirani u zasebne skupine u slijedu jedna iza druge (prema regionalnoj pripadnosti). 


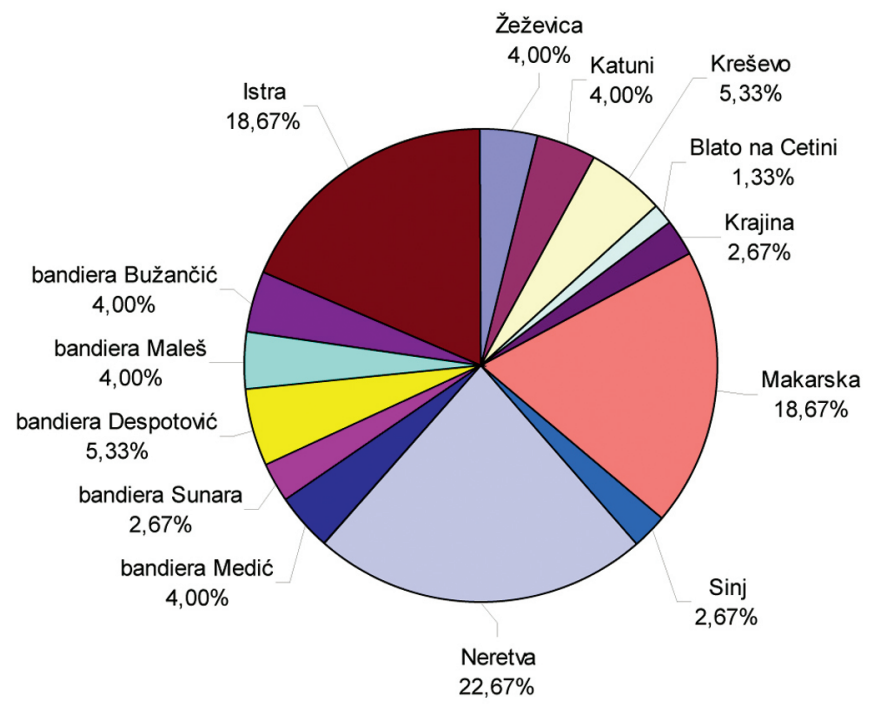

Grafikon 4. Zavičajno podrijetlo cernida iz osobne satnije pukovnika Nikole Medina prema popisu načinjenom u Mletcima 31. prosinca 1796. godine

\section{ZAKLJUČAK}

Paštrovići - područje u današnjem Crnogorskom primorju, smješteno između mora i područja Maina, Braića, Crmnice i Spiča - još su od konca kasnog srednjeg vijeka bili izrazito izloženi osmanskim prodorima. To je $s$ vremenom uzrokovalo brojna prekomorska iseljavanja (od Veneta i Mletaka do Apulije), ali i aktivno i zapaženo uključivanje Paštrovića u mletačke vojne snage. Na osnovi istraživanja gradiva iz središnje mletačke državne pismohrane (ponajprije fonda Inquisitori sopra l'amministrazione dei pubblici ruoli - ureda za novačenje) moguće je, kada je riječ o 18. stoljeću, vrlo precizno utvrditi udio vojnika iz ovoga kraja u prekomorskim postrojbama Serenissime, a to su pješaci (Fanti oltramarini) i konjanici (Croati a cavallo, Cavalleria Croati). Paštrovići su dominantno bili usmjereni na pješačke postrojbe, a neki od njih - poput članova obitelji Bečić i Medin - stekli su zapažene časničke činove (pukovnik Juraj Medin, bojnik Stjepan te niz kapetana i nižih časnika). U ovome prilogu, koji ne teži cjelovitosti i otvara nove istraživačke mogućnosti, u fokusu je bilo utvrđivanje pojedinih sastavnica iz vojne karijere Nikole Medina, odvjetka katoličke obitelji koja je nosila i naziv conti di Castel Lastva, djelatnog u drugoj polovici 18. stoljeća. Godine 1768. zabilježen kao dokapetan, a ubrzo potom kao kapetan, Nikola je Medin od oko 1785. do 1797. godine obnašao čin pukovnika 
mletačkih prekomorskih pješaka. Neke podatke o njegovu djelovanju saznajemo i iz Državnog arhiva u Zadru (fond: Generalni providuri za Dalmaciju i Albaniju), ali ponajprije iz gradiva sačuvanog u sklopu spomenute državne magistrature za novačenja. Na osnovu tih spisa saznajemo za sastav njegove pukovnije kroz duži niz godina, dobivamo uvid u djelovanje ostalih časnika, točnije mjesta njihova popisivanja njihovih satnija.

U radu su se analizirala četiri popisa Nikoline osobne satnije, nastala u rasponu od 1788. do 1796. godine, dakle u posljednjim godinama opstojanja Mletačke Republike. Ovi su podatci posebno zanimljivi jer govore o svojevrsnoj transformaciji tada aktivnih pukovnija i njima pripadajućih satnija kada se uslijed predstojećih ratnih opasnosti uzrokovanih Napoleonovim pohodima broj vojnog ljudstva naglo povećava. Raščlamba spisa koji se odnose na Nikolinu osobnu satniju, a takvih primjera nalazimo i u slučaju drugih vojnih zapovjednika zavičajem s istočne obale Jadrana, pokazuje da novačenje profesionalnih pješaka nije bilo dovoljno već se tada posezalo za uključivanjem pripadnika teritorijalne milicije (cernide, krajine). Uvidom u spise Nikoline osobne satnije razvidno je da su profesionalni vojni kadar ponajprije činili vojnici iz Dalmacije, točnije iz ruralnih dijelova na prostoru od Zadra do Neretve. Ono što donosi osobitost vremena djelovanja pukovnika Medina je uključivanje cernida koji su postojeću satniju brojčano znatno povećavali. Ovdje su potanko raščlanjeni podatci o zavičajnom podrijetlu kako profesionalnih vojnika tako i cernida te oni - u primjeru potonjih vojnika - pokazuju da njihovo podrijetlo najvećim dijelom možemo tražiti u dalmatinskom zaleđu. Naposljetku, rečeni podatci vrijedan su izvor ne samo za poznavanje tijeka vojne karijere pukovnika Nikole Medina već nam izravno govore i o mletačkoj vojnoj politici vezanoj za njezine kopnene i prekomorske stečevine na samom zalazu ranog novovjekovlja, ali i o malenim, običnim ljudima iz dalmatinskih sela koji su dio svoga života proveli pod stijegom Svetog Marka. 


\section{Prilog 1.}

Popis časnika, dočasnika i vojnika u osobnoj satniji pješačkog pukovnika Nikole Medina (Archivio di Stato di Venezia - fondo 0715 - Inquisitori sopra l'amministrazione dei pubblici ruoli, b. 650. Fanti Oltramarini, Reggimento Medin Nicolò, Mletci, 30. lipnja 1788.). ${ }^{36}$

1. Pukovnik (Colonnello): Nikola Medin

2. Dokapetan (Capitan tenente): Zuanne Rosani

3. Zastavnik (Alfier): Zuanne Benedetti

4. Narednik (Sargente): Josip Mialović - Antun

5. Kaplar (Caporal): Marko Krapanić - Marko - Primošten

6. Kaplar (Caporal): Ivan Vrbanić - Grgur - Istra - 24 - srednjeg rasta - smeđokos

7. Kaplar (Caporal): Mijat Lisac - Stijepo

8. Kadet (Cadetto): Teodoro Cortese

9. Bubnjar (Tamburo): Petar Cvitanović - Šimun

10. Pifarist (Piffaro): Mijo Radošević - Frane - Skradin - srednjeg rasta - smeđokos Vojnici (Soldati):

11. Cvjetko Večerina - Petar

12. Ambroz Lozi - Toma - Biograd (na Moru)

13. Frane Biljan - Antun - Pag

14. Mate Pešušić - Nikola - Zadar

15. Jure Stanac - Frane - Biljane

16. Mate Poleš - Jure - Rogoznica

17. Nikola Jerko - Petar - Zlosela (Pirovac)

18. Nikola Kančić - Grgur - Zlosela (Pirovac)

19. Jovo Radović - Marko - Skradin

20. Petar Popović

21. Šime Cvitanović

22. Frane Krančević - Šime - Lišane (Ostrovičke)

23. Frane Bonilević - Ante - Raštane

24. Luka Kazaro (Cazzaro) - Petar - Pađene - 18 - srednjeg rasta - smeđokos

25. Aleksa Vukobratović - Luka - Pađene - 18 - srednjeg rasta - smeđokos

26. Mate Danžić - Miko - Motovun

27. Jakov Grubišić - Frane - Makarska - 27 - srednjeg rasta - smeđokos

28. Marko Karlengo - Bartol - Pag - 25 - srednjega rast - smeđokos

29. Frane Komarić - Petar - Sinj - 26 - srednjeg rasta - smeđokos

36 Vojnici se navode slijedom upisa u dokument, a uz osnovne podatke (ime, prezime, ime oca, zavičajno podrijetlo), navode se, ako su upisani, podatci o njihovoj dobi, staturi i boji kose. Potrebno je napomenuti da se prezimena donose onako kako su izvorno upisana u dokument. S obzirom na činjenicu da su popisivači nerijetko griješili pri upisu, ali i da sami vojnici nisu uvijek, najčešće radi problema s kriminalnom prošlošću, davali točne podatke, dio prezimena ne može se u potpunosti rekonstruirati. 
30. Mijat Davanzo - Stjepan - Motovun - 23 - srednjeg rasta - smeđokos

31. Frane Kokolić - Jure - Rovinj - 30 - srednjeg rasta - smeđokos

32. Mihovil Trinka - Krsto - Hrvatska (Croato) - 20 - srednjeg rasta - smeđokos

33. Mate Kalčić - Mate - Istra - 26 - srednjeg rasta - smeđokos

34. Toma Kurta/Korta - Gašpar - Murter - 20 - srednjeg rasta - smeđokos

35. Marko Turčinović - Marko - Murter - 24 - srednjeg rasta - smeđokos

36. Jakov Škarpić - Toma - Murter - 18 - srednjeg rasta - smeđokos

37. Stipan Markovina - Nikola - 25 - srednjeg rasta - smeđokos

38. Mate Matešić - Marko - 22 - srednjeg rasta - smeđokos

39. Nikola Sladović/Sladoljev - Ive - Vodice - 20 - srednjeg rasta - smeđokos

40. Jure Čičin (Cicich) - Toma - Vodice - 20 - srednjeg rasta - smeđokos

41. Ante Čičin (Cicich) - Mate - Vodice - 20 - srednjeg rasta - smeđokos

42. Ante Cvetnić/Sfetnić - Bartol - Poreč - 20 - srednjeg rasta - smeđokos

43. Pavao Brčić - Ivan - Šibenik - 26 - srednjeg rasta - smeđokos

44. Marko Dragić (Dragili) - Jadre - Tribanj - 18 - srednjeg rasta - smeđokos

45. Ilija Milošević - Matija - Knin - 22 - srednjeg rasta - smeđokos

46. Grga Grapić - Luka - Primošten - 18 - srednjeg rasta - smeđokos

47. Šime Blažević - Šime - Primošten - 19 - srednjeg rasta - smeđokos

48. Josip Blažević - Kristijan - Rijeka - 18 - srednjeg rasta - smeđokos

49. Lazo Tokić - Vojko (?) - Knin - 22 - srednjeg rasta - smeđokos

50. Marko Malešević - Ilija - Petrovo polje - 25 - srednjeg rasta - smeđokos

51. Jakov Mičić - Antun - Klis - 25 - srednjeg rasta - smeđokos

52. Šime Sladaković - Ilija - Skradin - 25 - srednjeg rasta - smeđokos

53. Roko Marija Rokić - Dominik - Zadar

54. Petar Grapić - Pave - Sinj - srednjeg rasta - smeđokos

Naknadno dopisani:

1. Kadet (Cadetto): Petar Valeri

Vojnici (Soldati):

2. Mijat Miletić - Božo - Neretva

3. Franjo Donadelli - Antun - Kopar

4. Frane Škrlić - Gašpar - Rab

5. Nikola Maljevac - Frane - Rab

6. Mate Žanko - Ante - Pag

7. Antun Dragonja - Miho - Pag

8. Mate Pamić - Frane

9. Dominik Žustrović - Jakov - Krk

10. Marin Trljević - Ante - Novigrad (zadarski)

11. Frane Čilanac (Chilanas) - Mate - Novigrad (zadarski)

12. Antun Boneta - Toma - Zadarsko okružje (Contado di Zara)

13. Grgur Trljević - Grga - Novigrad (zadarski)

14. Marko Marušić - Frane - Motovun

15. Mate Šain - Jakov - Turanj

16. Frane Strpić - Šime - Biograd (na Moru)

17. Stipan Škugor - Antun - Šibenik 
18. Ilija Babić - Antun - Knin

19. Mate Dević - Martin - Zadar

20. Jure Grubišić - Antun - Makarska

21. Aleksa Graovac - Jakov

22. Grgo Mrkvar - Mate

23. Antun Braus - Miho

24. Mate Franešić - Ive

25. Mate Milaković - Marko

26. Lovre Milić - Mate - Tisno

27. Šime Vertko - Antun - Islam

28. Petar Prizmić - Antun - Korčula

29. Grgo Linić - Mate - Motovun

30. Dominik Krpantić - Antun - Osor

31. Ivan Radulović - Miko

32. Antun Raković - Frane - Kolarina

33. Toma Bočić - Antun - Šibenik

34. Matija Tomašić - Jure

35. Andrija Nikolić - Frane

36. Josip Nenković - Miho - Zadar

37. Marko Nenković - Josip -Zadar

38. Antun Vučeta - Miho

39. Luka Limbe - Toma

40. Jovan Rašković - Marko - Tisno

41. Mate Rašić - Frane

42. Mate Miš - Mate - Tisno

43. Marko Zakulić - Ive - Klis

44. Luka Boban - Aleksa - Šibenik

Prekobrojni (Sopranumerati):

1. Viši kapetan (Capitano supremo): Nikola Barbarić

2. Viši zastavnik (Alfier supremo): Marko Barbarić

3. Zastavnik (Alfier): Nikolica Medin

4. Zastavnik (Alfier): Andrija Durante

5. Zastavnik (Alfier): Ivan Dima

6. Zastavnik (Alfier): Ivan Andrija Mihovilović

7. Zastavnik (Alfier): Juraj Kumbat

8. Poručnik (Tenente): Agustin Kožul

9. Narednik (Sargente): Petar Oršić

10. Narednik (Sargente): Juro Banovac

11. Kaplar (Caporal): Antun Paramitiati

12. Kaplar (Caporal): Ellia Stratti

13. Kaplar (Caporal): Jure Petrović

14. Kaplar (Caporal): Giulio Napoli

15. Kapelan (Cappellano): o. Franjo Bašić

16. Kapelan (Cappellano): Ivan Ballarin 
17. Mornar (Mariner): Bernardo Chiappe

18. Mornar (Mariner): Vincenzo Anilier

19. Mornar (Mariner): Girolamo Botazza

20. Mornar (Mariner): Domenico Daltri

21. Mornar (Mariner): Anzolo Bonivento

22. Mornar (Mariner): Paolo Scarpa

23. Mornar (Mariner): Iseppo Bonaldo

24. Mornar (Mariner): Antonio Basilisco

25. Mornar (Mariner): Nikola Brkanić

26. Mornar (Mariner): Francesco de Rossi

27. Mornar (Mariner): Antonio Bonivento

28. Mornar (Mariner): Zuanne Capella

29. Mornar (Mariner): Vincenzo Mora

30. Mornar (Mariner): Iseppo Chivran

31. Mornar (Mariner): Santo Zanato

32. Mornar (Mariner): Antonio Ravagnato

33. Mornar (Mariner): Marco Marconi

\section{Prilog 2.}

Popis časnika, dočasnika i vojnika u osobnoj satniji pješačkog pukovnika Nikole Medina (Archivio di Stato di Venezia - fondo 0715 - Inquisitori sopra l'amministrazione dei pubblici ruoli, b. 651. Fanti Oltramarini, Reggimento Medin Nicolò, Zadar, 25. ožujak 1792.).

1. Pukovnik (Colonnello): Nikola Medin

2. Narednik (Sargente): Jure Banovac

3. Kaplar (Caporal): Ivan Jelinić

4. Kadet (Cadetto): Petar Ivan Andrija Burović - Boka kotorska

5. Bubnjar (Tamburo): Ivan Sdubić - Krstitelj - Pag

6. Pifarist (Piffaro): Ilija Šarić - Jure - Banjevci

Vojnici (Soldati):

7. Petar Galešić - Jure - Posedarje

8. Dujam Cvitanović - Stipan - Makarska

9. Mate Miličić - Jure - Makarska

10. Matija Donica - Luka - Zemunik

11. Grga Marišić - Andrija - Kukljica

12. Andrija Đurešić - Karlo

13. Šime Sobrić - Pave - Zlosela (Pirovac)

14. Antun Perišin - Roko - Zadar

15. Križan Berčić - Ivan - Kruševo

16. Filip Radulić - Frane - Grab

17. Petar Kušević - Stojan - Vis 
18. Mate Bogavčić - Todor - Rogoznica

19. Jakov Agostini - Blaž - Istra

20. Grgo Milotina - Mate

21. Mate Balinović - Nikola - Kaštela

22. Nikola Milotina - Filip - Vrsi

23. Luka Tomanović - Jure - Kotor

24. Marin Kunac - Mate - Podgorje

25. Antun Feličević - Jure - Podgorje

26. Ivan Rukavina - Mate - Karlovac

27. Adam Ivanić - Mijo - Biograd (na Moru)

28. Marko Marković - Božo - Crna Gora

29. Nikola Dragičević - Petar - Makarska

30. Šimun Ančić - Nikola - Bilišane

31. Vid Petrović - Ante - Privlaka

32. Niko Franko - Niko - Rab

33. Jure Bobić - Marko - Gospić

34. Antun Mitrović - Ivan - Zelengrad

35. Bože Borić - Luka - Trogir

36. Ivan Bistričić - Jakov - Pag

37. Frane Krisolović - Antun - Pag

38. Mate Peras - Petar - Rab

Naknadno dopisani:

1. Zastavnik (Alfier): Nikola Nakić

2. Kaplar (Caporal): Krstitelj Roščević - Antun - Istra

Vojnici (Soldati):

3. Ive Grubišić - Mate - Pag

4. Jure Jurjević - Marko - Kruševo

5. Frane Tomašević - Jure - Zadar

6. Toma Polegubić - Bare

7. Filip Ljubičić - Šime - Šibenik

8. Marijan Tistanić - Pere

9. Roko Marija Rokić - Dominik

10. Marin Vešić - Frane - Neretva

11. Dominik Draganić - Mihovil

12. Pave Žunić

13. Mate Slavinić

14. Toma Meštrović - Miloš - Vrgorac

15. Mate Žeravić - Grgo - Istra

16. Matija Mikelica - Pave - Kranjska

17. Ilija Vučetin - Vučeta - Crna Gora

18. Gabrijel Sion/Šijan - Mihovil - Šibenik

19. Antun Brakus - Jakov - Trebinje 


\section{Prilog 3.}

Popis cernida (pripadnika teritorijalne milicije) u osobnoj satniji pješačkog pukovnika Nikole Medina (Archivio di Stato di Venezia - fondo 0715 Inquisitori sopra l'amministrazione dei pubblici ruoli, b. 652. Fanti Oltramarini, Reggimento Medin Nicolò, Vicenza, 24. lipnja 1794.).

1. Kaplar (Caporal): Antun Vušković - Ivan - Blato na Cetini Vojnici (Soldati):

2. Antun Livić - Nikola - Žeževica

3. Mihovil Latković - Ivan - Žeževica

4. Andrija Čirović - Marko - Žeževica

5. Dujam Bolčić - Ivan - Žeževica

6. Matija Bajić - Ilija - Žeževica

7. Stjepan Litrić - Luka - Žeževica

8. Tadija Šestan - Ivan - Žeževica

9. Stipan Gilić - Petar - Žeževica

10. Ivan Popović - Antun - Žeževica

11. Ilija Paskorić - Antun - Žeževica

12. Grgur Jakos - Stjepan - Žeževica

13. Jakov Kustić - Juraj - Žeževica

14. Ilija Kekez - Šimun - Katuni

15. Juraj Narčić - Juraj - Katuni

16. Mihovil Zurgal (?) - Matija - Katuni

17. Petar Galot - Marko - Katuni

18. Josip Vrlić/Vilić - Ivan - Katuni

19. Stipan Mandušić - Andrija - Katuni

20. Juraj Merčep - Andrija - Katuni

21. Ivan Marduš - Šimun - Katuni

22. Andrija Poljak - Jadre - Katuni

23. Antun Družić - Juraj - Katuni

24. Luka Maser - Marko - Kreševo

25. Luka Maslov - Martin - Kreševo

26. Matija Lenšić - Luka - Kreševo

27. Stipan Biskupović - Ivan - Kreševo

28. Šimun Biskupović - Ivan - Kreševo

29. Luka Delić - Stjepan - Kreševo

30. Petar Ivanić - Jadre - Blato na Cetini

31. Nikola Škriljanović - Andrija - Blato na Cetini

32. Ivan Sladojević - Jadre - Blato na Cetini

33. Filip Perišić - Petar - Blato na Cetini

34. Ivan Zulić - Marko - Blato na Cetini

35. Antun Posarnić/Posenić - Ivan - Blato na Cetini

36. Matija Vuković - Nikola - Blato na Cetini

37. Šimun Sarcego - Šimun - Klis 


\section{Prilog 4.}

Popis cernida (pripadnika teritorijalne milicije) u osobnoj satniji pješačkog pukovnika Nikole Medina (Archivio di Stato di Venezia - fondo 0715 Inquisitori sopra l'amministrazione dei pubblici ruoli, b. 654. Fanti Oltramarini, Reggimento Medin Nicolò, Mletci, 31. prosinac 1796.).

Vojnici (Soldati):

1. Tadija Šestan - Ivan - Žeževica

2. Stipan Gilić - Petar - Žeževica

3. Jakov Kustić - Juraj - Žeževica

4. Petar Galot - Marko - Katuni

5. Josip Vrlić/Vilić - Ivan - Katuni

6. Andrija Poljak - Jadre - Katuni

7. Stipan Biskupović - Ivan - Kreševo

8. Luka Delić - Stjepan - Kreševo

9. Ivan Sladović - Jakov - Kreševo

10. Ivan Zulić/Culić - Marko - Kreševo

11. Antun Posarnić/Posenić - Ivan - Blato na Cetini

12. Matija Dostić - Marko - Krajina

13. Ivan Marchesi - Šimun - Krajina

14. Mate Bartulović - Mihovil - Makarska

15. Martin Aleksić - Jakov - Makarska

16. Mihovil Kraljević - Marko - Makarska

17. Petar Vukojević - Marti - Makarska

18. Ivan Cvitanović - Antun - Makarska

19. Juraj Smožbradić - Martin - Makarska

20. Marko Božić - Matija - Makarska

21. Stjepan Veličević - Juraj - Makarska

22. Pavao Bator - Petar - Makarska

23. Stjepan Donić - Matija - Makarska

24. Grgur Marušić - Antun - Makarska

25. Ivan Visković - Mihovil - Makarska

26. Franjo Lalić - Šimun - Makarska

27. Grgur Klako - Luka - Makarska

28. Jure Telarić - Frane - Sinj

29. Vicko Jurgač - Pavao - Sinj

30. Ivan Dropulić - Juraj - Neretva

31. Ivan Vuković - Andrija - Neretva

32. Petar Ciglieghe - Lovro - Neretva

33. Antun Prusac - Antun - Neretva

34. Stjepan Radoš - Andrija - Neretva

35. Antun Nikolas - Karlo - Neretva

36. Juraj Uršulić - Andrija - Neretva

37. Josip Marojević - Ivan - Neretva 
38. Šime Kadijević - Luka - Neretva

39. Antun Sentić - Marko - Neretva

40. Šimun Borac - Ivan - Neretva

41. Blaž Frleta - Nikola - Neretva

42. Antun Pauletić - Vid - Neretva

43. Petar Điković - Lovro - Neretva

44. Juraj Sočivica - Antun - Neretva

45. Vid Karamatić - Martin - Neretva

46. Franjo Musolin - Marin - Neretva

47. Jakov Vičić - Antun - bandiera Medić

48. Kuzma Striza - Marko - bandiera Medić

49. Stjepan Sorić - Matija - bandiera Medić

50. Ivan Bačerić - Ivan - bandiera Sunara

51. Mate Kursan - Frane - bandiera Sunara

52. Josip Tešija - Matija - bandiera Despotović

53. Jerko Tešija - Nikola - bandiera Despotović

54. Šimun Tešija - Dujam - bandiera Despotović

55. Ivan Čelan - Jerko - bandiera Despotović

56. Vicko Malvazija - Mihovil - bandiera Maleš

57. Marko Tadić - Grgo - bandiera Maleš

58. Antun Tadić - Toma - bandiera Maleš

59. Jakov Tešija - Dujam - bandiera Bužančić

60. Jure Bundić - Bože - bandiera Bužančić

61. Petar Tešija - Martin - bandiera Bužančić

62. Ivan Valente - Petar - Istra

63. Petar de Mori - Jakov - Istra

64. Dominik de Giorgi - Antun - Istra

65. Andrija Bošković - Andrija - Istra

66. Ante Radiković - Josip - Istra

67. Toma Koloburić - Vicko - Istra

68. Luka Bečić - Grgur - Vižinada

69. Antun Sabac - Antun - Vižinada

70. Antun Šuška - Dominik - Vižinada

71. Lovro Raffaelli - Grgur - Vižinada

72. Dominik Domini - Matija - Vižinada

73. Luka Legorić - Andrija - Kaštelir (Kaštelir Labinci)

74. Marko Dubac - Juraj - Kaštelir (Kaštelir Labinci)

75. Blaž Mikalić - Martin - Kaštelir (Kaštelir Labinci) 


\section{IZVORI I LITERATURA}

\section{IZVORI:}

Državni arhiv u Zadru, Generalni providuri za Dalmaciju i Albaniju (HR-DAZD1-GPDA).

Archivio di Stato di Venezia, Inquisitori sopra l'amministrazione dei pubblici ruoli (RI-ASVe-0715, Inquisitori ... pubblici ruoli).

\section{LITERATURA:}

Čoralić, Lovorka, Iz prošlosti Paštrovića, Historijski zbornik, sv. 49, Zagreb, 1996., 137 - 159.

Čoralić, Lovorka, Tragom oporuka bokeljskih i paštrovskih trgovaca u Mlecima (od kraja XV. do kraja XVI. stoljeća), Istorijski zapisi, god. 80, br. 1 - 4, Podgorica, 2007., 97 - 118.

ČorALIĆ, Lovorka, Bokeljski, paštrovski i budvanski iseljenici i mletački arsenal (XV-XVIII stoljeće), Godišnjak Pomorskog muzeja u Kotoru, sv. 57 - 58, Kotor, 2010., $17-27$.

Čoralić, Lovorka, Iseljenici iz Paštrovića u Zadru (XVI.-XIX. st.), Historijski zbornik, god. 64, br. 1, Zagreb, 2011., 1 - 27.

Čoralić, Lovorka, Iseljenici iz Paštrovića u Mlecima (15. - 18. stoljeće), Paštrouski almanah, sv. 2, Petrovac - Sveti Stefan, 2017., 525 - 546.

ČorAlić, Lovorka, Albanski vojnici u mletačkim prekojadranskim kopnenim postrojbama (18. stoljeće), Povijesni prilozi god. 37, br. 54, Zagreb, 2018. $185-186$.

Čoralić, Lovorka, Pukovnik mletačkih prekomorskih pješaka Juraj Medin (kraj 17. i početak 18. stoljeća), Historijski zbornik, god. LXXII, br. 1, Zagreb, 2019., $47-62$.

Čoralić, Lovorka, KATUŠIć, Maja, Šibenčani u mletačkim prekojadranskim kopnenim postrojbama (18. stoljeće), Radovi Zavoda za povijesne znanosti HAZU u Zadru, sv. 58, Zagreb - Zadar, 2016., 147 - 190.

Granić, Miroslav, Martinović, Denis, Plemstvo Kraljevine Dalmacije 1814. 1918., Zadar, 2018.

Heyer von Rosenfeld, Carl Georg Friedrich, Der Adel des Königreichs Dalmatien, Nürnberg, 1873. (pretisak: Zagreb, 1995.). 
Markulin, Nikola, Vojno poduzetništvo u Mletačkoj Dalmaciji i Boki za vrijeme Morejskog rata (1684. - 1699.), Radovi Zavoda za povijesne znanosti HAZU u Zadru, sv. 56, Zagreb - Zadar, 2014., 91 - 142.

Markulin, Nikola, Mletačka vojna organizacija u Dalmaciji i Boki od Morejskog rata (1684. - 1699.) do Požarevačkog mira 1718., doktorski rad, Zadar, 2015.

Markulin, Nikola, Vojno poduzetništvo u Mletačkoj Dalmaciji i Boki od 1700. do 1718. godine, Povijesni prilozi, god. 35, sv. 51, Zagreb, 2016., 159 - 196.

Vukmanović, Jovan, Paštrovići: Antropogeografsko-etnološka studija, Podgorica, 2002. 
Lovorka ČORALIĆ

\section{THE COLONEL OF PAŠTROVIĆI NIKOLA MEDIN - COMMANDER OF THE VENETIAN OVERSEAS INFANTRY FORCES AT THE END OF THE 18TH CENTURY}

\section{SUMMARY}

The paper focuses on the research of details from the military career of Nikola Medin, originally from Paštrovići (conte di Castel Lastva), a colonel of the Venetian overseas infantry (Fantiol tramarini) in the last decades of the Venetian Republic. The paper is based on the analysis of materials from the State Archives in Zadar (holdings: General Providuri for Dalmatia and Albania) and - to a greater extent - on the processing of documents from the Archivio di Stato di Venezia (holdings: Inquisitori sopra l'amministrazione dei pubblici ruoli). The introductory part of the paper summarises general data from the past of Paštrovići during the Venetian rule, with particular reference to the involvement of the local population in the Venetian trans-Adriatic land units (infantry: Fantiol tramarini and cavalry: Cavalleria Croati or Croati a cavallo). The share of the Medin family in the Venetian army is summed up, and their ranks are stated. Most of the work focuses on the analysis of data about the promotion of Nikola Medin from the rank of deputy captain to colonel. The focus is placed on an in-depth analysis of the list of his personal companies from 1788 to 1796 with emphasis on the native origin of the soldiers he personally commanded. It was determined that some of the soldiers could be counted in the professional infantry, while some of them belonged to the territorial militias, i.e. cernides. Attached are lists of military personnel in Colonel Medin's personal companies (compagnia propria) which are analysed here.

Keywords: Nikola Medin, Fantiol tramarini, Paštrovići, Venetian Republic, cernides, military history, 18th century. 